Article

\title{
Lasianosides A-E: New Iridoid Glucosides from the Leaves of Lasianthus verticillatus (Lour.) Merr. and Their Antioxidant Activity
}

\author{
Gadah Abdulaziz Al-Hamoud ${ }^{1,2}$, Raha Saud Orfali ${ }^{2, *}$, Shagufta Perveen ${ }^{2}$, Kenta Mizuno ${ }^{3}$, \\ Yoshio Takeda ${ }^{3}$, Tatsuo Nehira ${ }^{4}$, Kazuma Masuda ${ }^{4}$, Sachiko Sugimoto ${ }^{1}$, Yoshi Yamano ${ }^{1}$, \\ Hideaki Otsuka ${ }^{1,5}$ and Katsuyoshi Matsunami ${ }^{1, *}$ \\ 1 Graduate School of Biomedical and Health Sciences, Hiroshima University, 1-2-3 Kasumi, Minami-ku, \\ Hiroshima 734-8553, Japan; galhamoud@ksu.edu.sa (G.A.A.-H.); ssugimot@hiroshima-u.ac.jp (S.S.); \\ yamano@hiroshima-u.ac.jp (Y.Y.); otsuka-h@yasuda-u.ac.jp (H.O.) \\ 2 Department of Pharmacognosy, College of Pharmacy, King Saud University, Riyadh 11495, Saudi Arabia; \\ Shagufta792000@yahoo.com \\ 3 Faculty of Integrated Arts and Sciences, The University of Tokushima, 1-1 Minamijosanjima-Cho, Tokushima \\ 770-8502, Japan; tokushis1@yahoo.co.jp (K.M.); takeda@ias.tokushima-u.ac.jp (Y.T.) \\ 4 Graduate School of Integrated Arts and Sciences, Hiroshima University, 1-7-1 Kagamiyama, \\ Higashi-Hiroshima 739-8521, Japan; tnehira@hiroshima-u.ac.jp (T.N.); b163780@hiroshima-u.ac.jp (K.M.) \\ 5 Faculty of Pharmacy, Yasuda Women's University, 6-13-1 Yasuhigashi, Asaminami-ku, \\ Hiroshima 731-0153, Japan \\ * Correspondence: rorfali@ksu.edu.sa (R.S.O.); matunamil@hiroshima-u.ac.jp (K.M.); \\ Tel.: +966-11-8055014 (R.S.O.); +81-82-257-5335 (K.M.)
}

Received: 7 October 2019; Accepted: 3 November 2019; Published: 5 November 2019

\begin{abstract}
The genus Lasianthus (Rubiaceae) consists of approximately 180 species, of which the greatest species diversity is found in tropical Asia. Some of the Lasianthus species have been used in folk medicine to treat tinnitus, arthritis, fever, and bleeding. Lasianthus verticillatus (Lour.) Merr. (Syn. Lasianthus trichophlebus auct. non Hemsl.) is a shrub, branchlets terete about 1.5-3 m in height. This paper studies the chemical composition of the leaves of L. verticillatus for the first time, which resulted in the isolation of five undescribed iridoid glucosides, lasianosides A-E (1-5), together with three known compounds (6-8). The undescribed structures of isolated compounds (1-5) were characterized by physical and spectroscopic data analyses, including one-dimensional (1D) and two-dimensional (2D) NMR, IR, UV, and high-resolution electrospray ionization mass spectra (HR-ESI-MS). Furthermore, the electronic circular dichroism data determined the absolute configurations of the new compounds. The free radical scavenging properties of isolated compounds was assessed by 1,1-diphenyl-2-picrylhydrazyl (DPPH) radical scavenging assay, and their cytotoxicity was assessed toward human lung cancer cell line A549 by the 3-(4,5-dimethylthiazol-2-yl)-2,5-diphenyltetrazolium bromide (MTT) method. Among the isolated compounds, 3 and 4 displayed potent radical scavenging activities with $\mathrm{IC}_{50}$ values of $30.2 \pm 1.8$ and $32.0 \pm 1.2 \mu \mathrm{M}$, which were comparable to that of Trolox $(29.2 \pm 0.39 \mu \mathrm{M})$, respectively, while 5 possessed moderate activity with an $\mathrm{IC}_{50}$ value of $46.4 \pm 2.3 \mu \mathrm{M}$. None of the isolated compounds exerted cytotoxicity against human cell line A549. As a result, lasianosides C, D, and E have the potential to be non-toxic safe antioxidant agents.
\end{abstract}

Keywords: Lasianthus trichophlebus; Rubiaceae; DPPH; radical scavenging activity; cytotoxicity 


\section{Introduction}

Reactive oxygen species (ROS) are derived from exogenous (environmental pollution, cigarette smoke, UV irradiation, and toxic chemicals) and intracellular (mitochondrial energy generation) sources. The excessive ROS accumulation leads to oxidative stress through the reaction of ROS with biomolecules such as cell membrane lipids, proteins, and DNA, which causes a variety of chronic and degenerative disorders including cataract, rheumatoid arthritis, cancer, cardiovascular diseases, neurodegenerative disorders, and also aging. Therefore, a supplementation of exogenous antioxidants as free radical scavengers is thought to be an effective measure for preventing and repairing the damages caused by ROS [1].

Lung cancer is one of the leading causes of cancerous death for both the male and female in the world. Treatment options for lung cancer include surgery, chemotherapy, and radiation therapy. However, the prognosis is still unsatisfactory, probably because of its high invasion and metastatic activity to various organs (e.g., brain, lymph nodes, bones, and liver), the ability to evade apoptosis, the resistance to antitumor drugs, and the severe side effects of antitumor drugs and radiotherapy themselves. Therefore, there is an increased and continued demand for new agents to treat and prevent this life-threatening disease [2].

A great number of natural bioactive compounds have been isolated from various natural sources and have contributed to the development of more than $60 \%$ of current clinical drugs [3]. Thus, we still rely on Mother Nature, including plants' secondary metabolites for the discovery of seed and lead chemicals in serendipitous way. Plants of the genus Lasianthus (Rubiaceae) are distributed in Asia, Africa, America, and Australia, with about 180 species in total. Most of the species are found in tropical Asia, while only one species exists in Australia [4,5]. Some of the species have been used in folk medicine to treat tinnitus, arthritis, fever, and bleeding [6-9]. Previous chemical studies on various species of genus Lasianthus have resulted in the isolation of iridoids with diverse skeletons, especially asperuloside and deacetyl asperulosidic acid, in addition to bis-iridoid glucosides, anthraquinones, megastigmane glucosides, and terpenes [8,10-15]. L. verticillatus (Lour.) Merr. (Syn. L. trichophlebus auct. non Hemsl.) is a shrub, branchlets terete of about 1.5-3 $\mathrm{m}$ in height [16]. L. verticillatus has been used as a traditional, analeptic, or restorative medicine in Northern Thailand and India [17]. Recently, Napiroon et al. reported thin-layer chromatography (TLC) and HPLC analyses of the lipophilic fraction of the leaves of L. verticillatus to reveal the presence of terpenoids, alkaloids, phenolic compounds, and coumarines by the reaction color of spraying reagents. The seed germination and seedling growth of weeds and anti-fungal activity against a plant pathogen, Colletotrichum gloeosporioides, were reported. However, a detailed chemical analysis of the secondary metabolites and their biological activities has not yet been performed. This study is the first report on the chemical constituents of the polar fraction (1-BuOH) of the leaves of $L$. verticillatus, and afforded five new iridoid glucosides, lasianosides A-E (1-5), together with three known compounds, an iridoid (6) (compound 2 in Takeda et al., 2002 [11], designated hereafter as lasianol by the author, YT), deacetyl daphylloside (7), and daphylloside (8) [18] (Figure 1). This paper deals with the structural elucidation of isolated compounds including the absolute configuration of new compounds, and the evaluation of their antioxidant activities by 1,1-diphenyl-2-picrylhydrazyl (DPPH) free radical scavenging assay, and cytotoxic activity against human lung cancer cell line (A549) that is frequently used for the study of lung cancer and the initial drug screening, by 3-(4,5-dimethylthiazol-2-yl)-2,5-diphenyltetrazolium bromide (MTT) assay. 


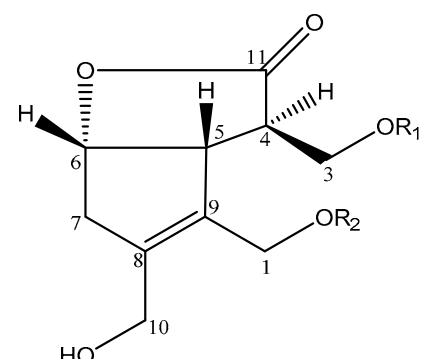

$\begin{array}{llll} & \mathbf{R}_{\mathbf{1}} & \mathbf{R}_{\mathbf{2}} \\ \mathbf{1} & \mathrm{H} & \mathrm{Glc} \\ \mathbf{2} & \mathrm{Glc} & \mathrm{H} \\ \mathbf{6} & \mathrm{H} & \mathrm{H}\end{array}$
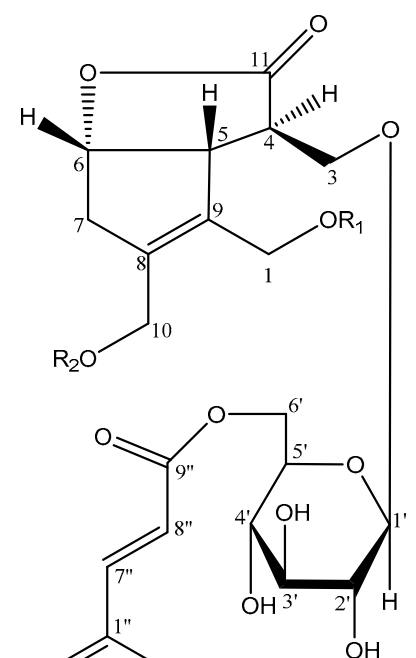

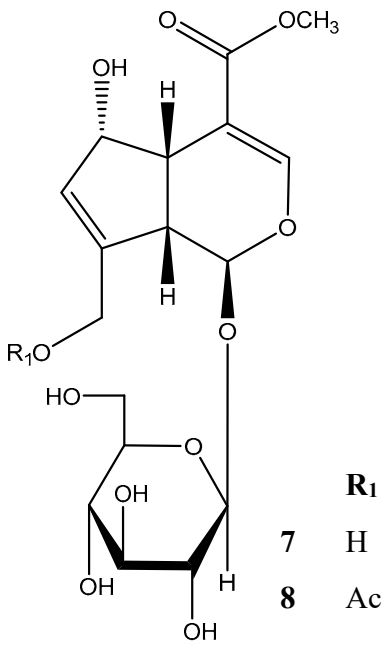

$\mathbf{R}_{2}$

$\mathrm{H}$

$\mathrm{H}$

$\mathrm{Ac}$

Figure 1. Isolated compounds from Lasianthus verticillatus (1-8).

\section{Results and Discussion}

\subsection{Isolation and Spectroscopic Analyses of the Compounds}

The 1-BuOH fractions of methanolic extract of Lasianthus verticillatus (Lour.) Merr. leaves were separated by solvent fractionation, various column chromatographies (CC), and HPLC to afford compounds 1-8 (Figure 1). The chemical structures of the isolated compounds were investigated and identified through intensive spectroscopic analyses based on UV-visible, one-dimensional (1D) and two-dimensional (2D) NMR, and high-resolution electrospray ionization mass spectra (HR-ESI-MS) as follows (Figures S1-S48).

\subsubsection{Chemical Structure of Lasianoside A}

Lasianoside $\mathrm{A}(\mathbf{1}),[\alpha]^{22} \mathrm{D}^{-20.6}$, was obtained as viscous colorless syrup. Its molecular formula was determined as $\mathrm{C}_{16} \mathrm{H}_{24} \mathrm{O}_{10}$ based on a sodium adduct ion at $\mathrm{m} / \mathrm{z} 399.1263[\mathrm{M}+\mathrm{Na}]^{+}$(calcd for $\mathrm{C}_{16} \mathrm{H}_{24} \mathrm{O}_{10} \mathrm{Na}$ 399.1262) in HR-ESI-MS, which suggests five degrees of unsaturation. The IR spectrum exhibited absorption bands at 3390 and $1748 \mathrm{~cm}^{-1}$, which indicated the presence of hydroxy and a five-membered lactone ring, respectively. ${ }^{1} \mathrm{H}-\mathrm{NMR}$ spectrum displayed signals of four methylenes, including a methylene at $\delta_{\mathrm{H}} 2.75(\mathrm{br} \mathrm{d}, J=18.1 \mathrm{~Hz})$ and $2.95(\mathrm{dd}, J=18.1,6.3 \mathrm{~Hz})$, and three methylenes attached to oxygen at $\delta_{\mathrm{H}} 3.91(2 \mathrm{H}, \mathrm{d}, J=3.9 \mathrm{~Hz}), 4.20(\mathrm{br} \mathrm{d}, J=13.4 \mathrm{~Hz}), 4.24(\mathrm{br} \mathrm{d}, J=13.4 \mathrm{~Hz}), 4.28(\mathrm{br}$ $\mathrm{d}, J=12.0 \mathrm{~Hz})$, and $4.61\left(\mathrm{br} \mathrm{d}, J=12.0 \mathrm{~Hz}\right.$ ) (Table 1). Furthermore, the ${ }^{1} \mathrm{H}-\mathrm{NMR}$ data supported the existence of three methines; two of them showed signals at $\delta_{\mathrm{H}} 2.99(\mathrm{~m})$ and $3.73(\mathrm{~d}, J=6.3 \mathrm{~Hz})$, and an oxygenated methine proton at $\delta_{\mathrm{H}} 5.14(\mathrm{t}, J=6.3 \mathrm{~Hz})$.

Taking into consideration the above-mentioned molecular formula and degree of unsaturation, the 16 carbon signals in the ${ }^{13} \mathrm{C}-\mathrm{NMR}$ spectrum are thus ascribable to the presence of three oxymethylenes $(\delta \mathrm{c} 58.4,63.3,64.4)$, an oxymethine $(\delta \mathrm{c} 83.2)$, as well as two unsaturated quaternary carbons $(\delta \mathrm{c}$ $134.4,140.2)$ and carbonyl carbon ( $\delta c$ 180.9) (Table 2). The COSY (correlation spectroscopy) (Figure 2) correlations between $\mathrm{H}_{2}-3 / \mathrm{H}-4$ and $\mathrm{H}-4 / \mathrm{H}-5$ together with the $\mathrm{HMBC}$ (heteronuclear multiple bond connectivity correlation) (Figure 2) correlations from H-5 to C-11 ( $\delta \mathrm{c} 180.9), \mathrm{C}-3$ ( $\delta \mathrm{c} 63.3), \mathrm{C}-8$ ( $\delta \mathrm{c} 140.2)$, and C-9 $(\delta \mathrm{c} 134.4)$ and from H-6 to C-11 ( $\delta \mathrm{c} 180.9)$ indicated that 1 shared the same core structure as 
6 [11]. Moreover, the $1 \mathrm{D}$ NMR data of 1 also gave an anomeric proton signal at $\delta_{\mathrm{H}} 4.30(\mathrm{~d}, J=7.9 \mathrm{~Hz})$, in addition to six carbon signals at $\delta_{\mathrm{c}} 103.8,78.0,78.0,75.1,71.6$, and 62.8 that belong to a glucose moiety, which means that 1 was the glucoside of $\mathbf{6}$. The HMBC correlation from the anomeric proton of glucose $\mathrm{H}-1^{\prime}\left(\delta_{\mathrm{H}} 4.30\right)$ to $\mathrm{C}-1$ ( $\left.\delta \mathrm{c} 64.4\right)$ of the aglycone moiety indicated the glucosylation position on C-1. The presence of a D-glucose moiety was confirmed by the acid hydrolysis of $\mathbf{1}$ followed by HPLC analysis with a chiral detector. The coupling constant $(J=7.9 \mathrm{~Hz})$ of $\mathrm{H}-1^{\prime}$ indicated $\beta$ linkage for glucose moiety. The relative configuration was established by NOESY analysis (Figure 3). The correlation between $\mathrm{H}-3 / \mathrm{H}-5, \mathrm{H}-5 / \mathrm{H}-6$, and $\mathrm{H}-6 / \mathrm{H}-7$ suggested a $\beta$-orientation, while the absence of correlation signals between $\mathrm{H}-4$ and $\mathrm{H}-6$ suggested a $\alpha$-orientation. The chemical shift values and the coupling patterns of aglycone moiety were essentially superimposable to 6 except for the glucosylation position C-1, which supported the relative stereochemistry of $\mathbf{1}$, as shown in Figure 1. The absolute stereochemistry of $\mathbf{1}$ was elucidated by comparison of the circular dichroism (CD) spectrum. The positive cotton effect at $221 \mathrm{~nm}(\Delta \varepsilon=+0.854)$ showed the same absolute stereochemistry with lasianol (6) [11], and consequently the structure of $\mathbf{1}$ was determined to be a $(4 R, 5 R, 6 S)$ configuration, i.e., 1-O- $\beta$-D-glucopyranoside of 6 .

Table 1. ${ }^{1} \mathrm{H}$ NMR data of compounds $1-5\left(500 \mathrm{MHz}, \mathrm{CD}_{3} \mathrm{OD}, \delta\right.$ in ppm, J in $\left.\mathrm{Hz}\right)$.

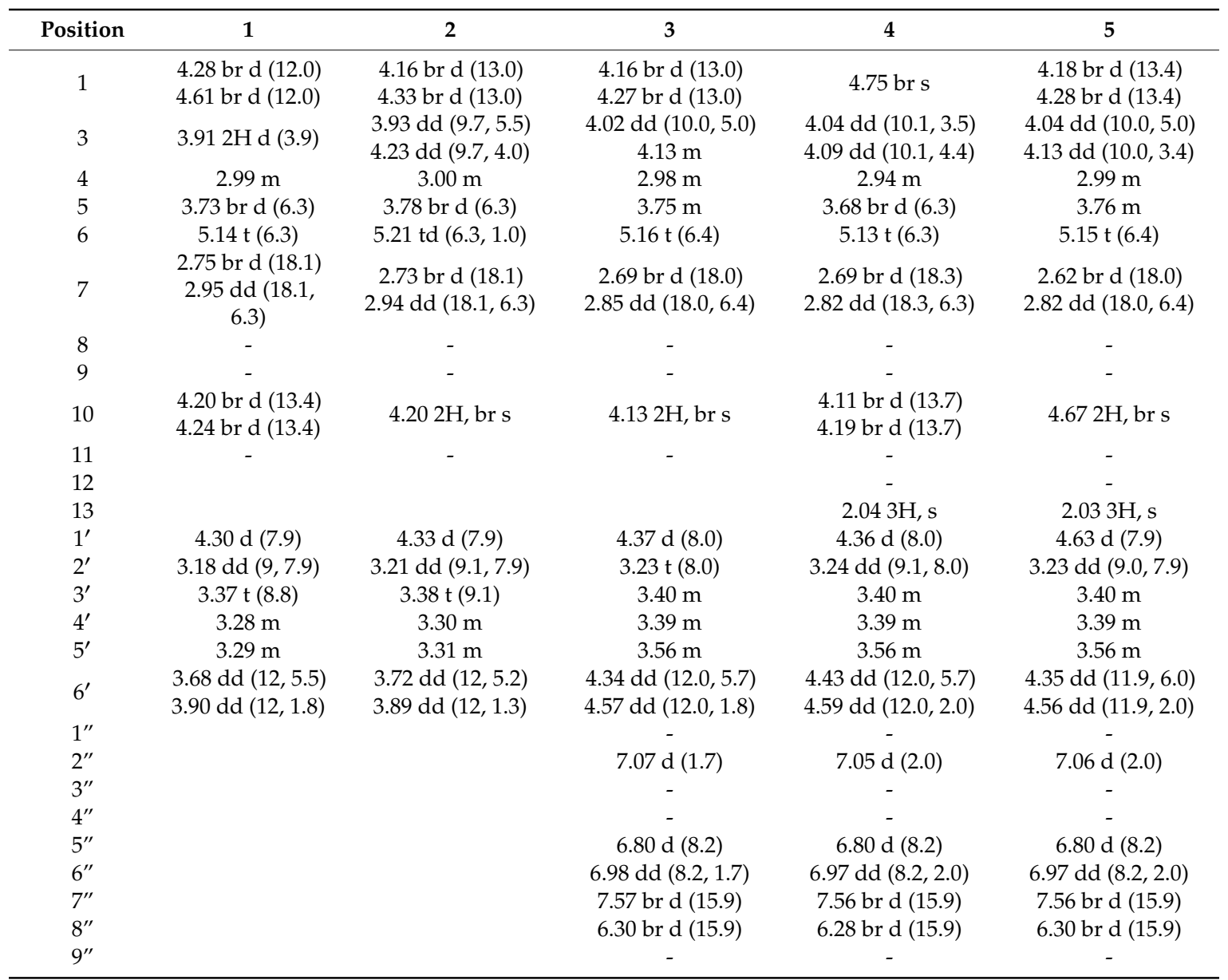



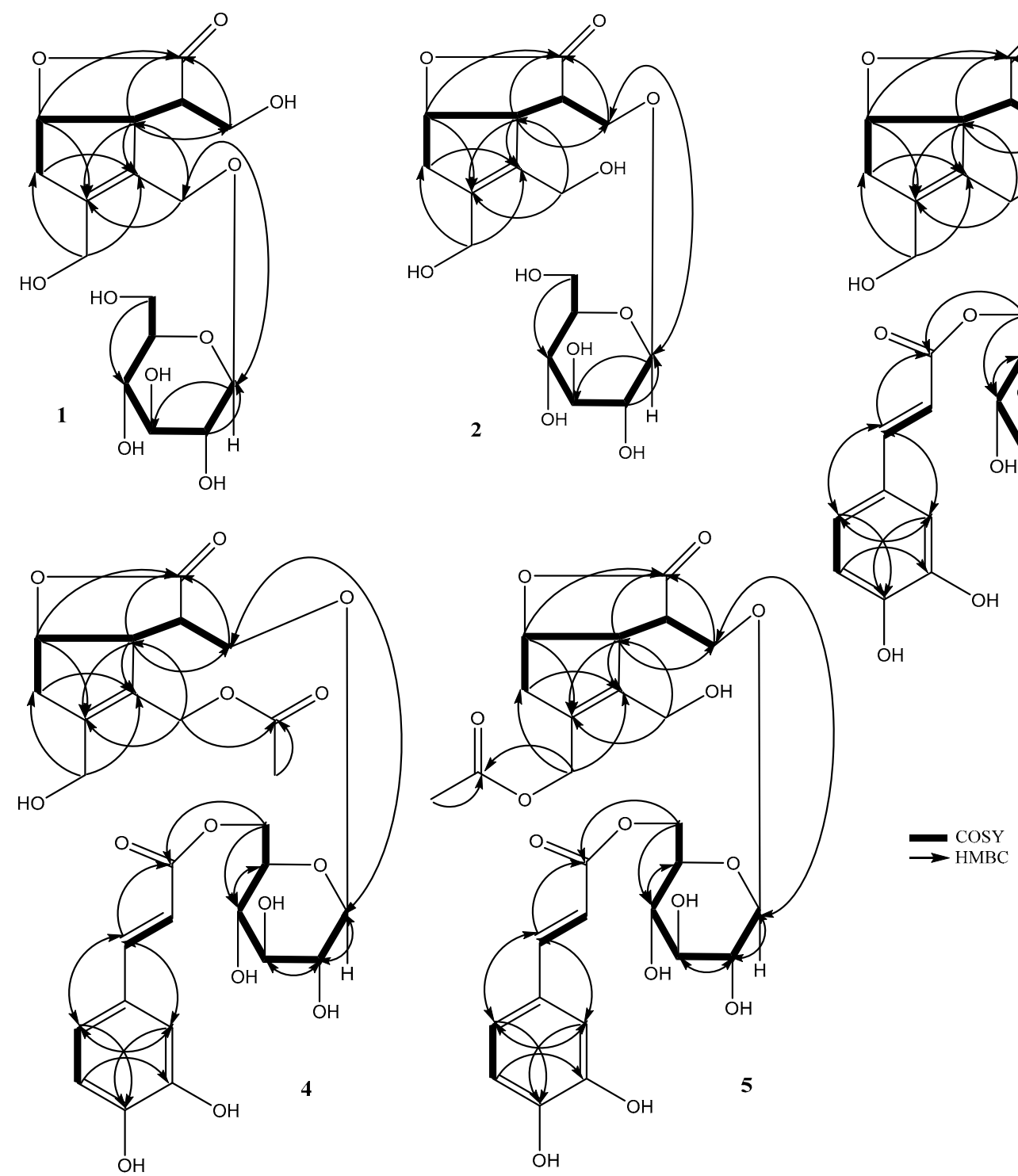

Figure 2. Correlation spectroscopy (COSY) and heteronuclear multiple bond connectivity correlation (HMBC) correlations of $\mathbf{1}-\mathbf{5}$. 


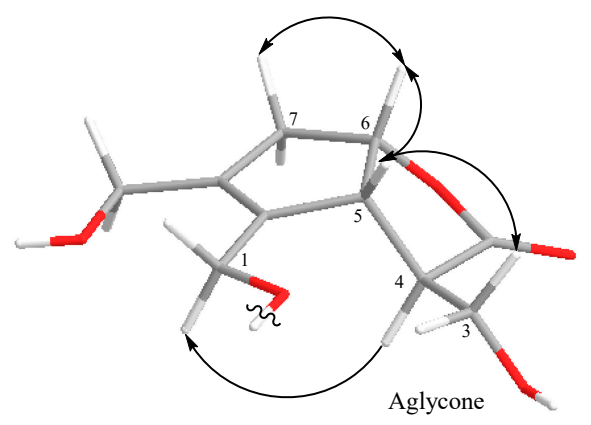

1

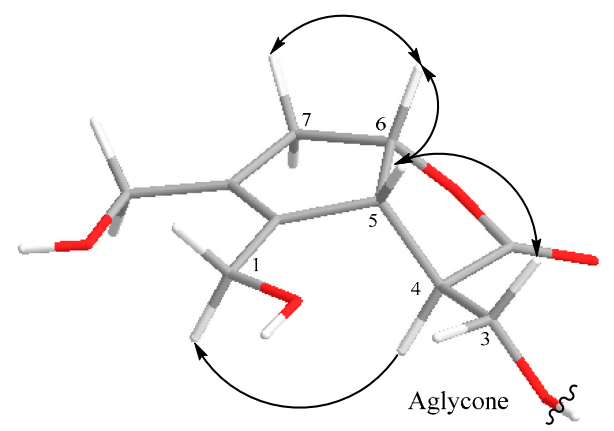

3

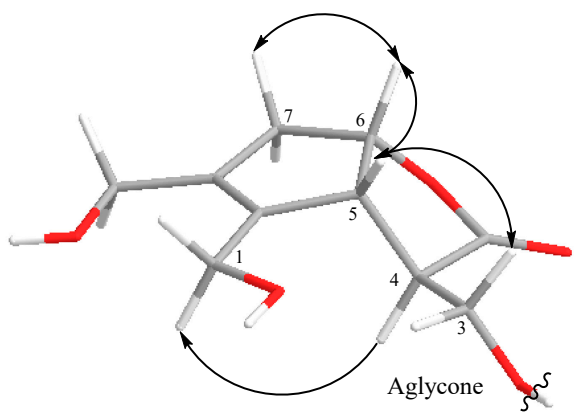

2

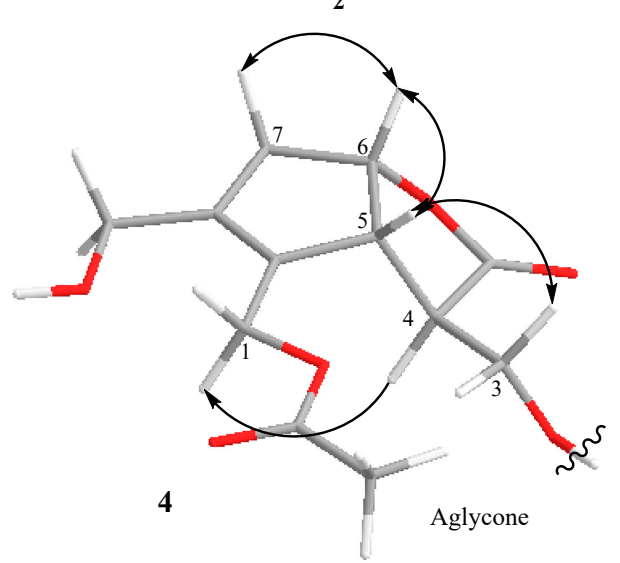

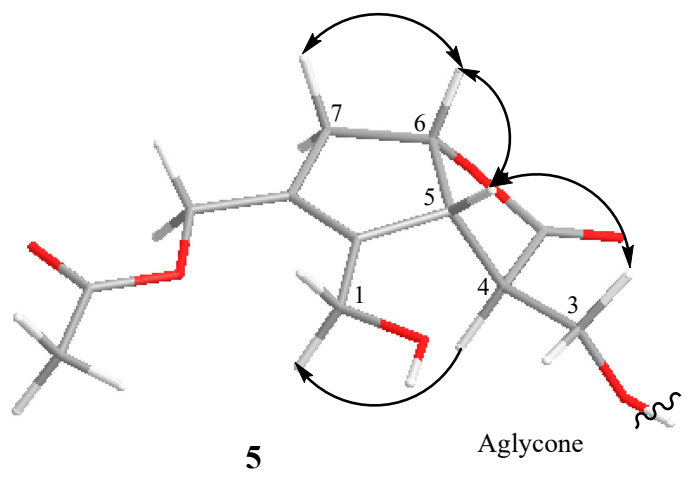

Figure 3. Key NOESY correlations of $\mathbf{1}-\mathbf{5}$.

\subsubsection{Chemical Structure of Lasianoside B}

Lasianoside $B(2),[\alpha]^{22} \mathrm{D}^{-26.6}$, was isolated as viscous colorless syrup and displayed the same molecular formula $\mathrm{C}_{16} \mathrm{H}_{24} \mathrm{O}_{10}$ of $\mathbf{1}$ in HR-ESI-MS at $m / z 399.1265[\mathrm{M}+\mathrm{Na}]^{+}$(calcd for $\mathrm{C}_{16} \mathrm{H}_{24} \mathrm{O}_{10} \mathrm{Na}$ 399.1262). Analysis of $1 \mathrm{D}$ and 2D NMR data (Tables 1 and 2) revealed that the data of 2 were very similar to those of 1 except for apparent differences for the signals of $\mathrm{H}_{2}-1$ [ $\delta_{\mathrm{H}} 4.16(\mathrm{br} \mathrm{d}, J=13.0 \mathrm{~Hz})$, $4.33(\mathrm{br} \mathrm{d}, J=13.0 \mathrm{~Hz})]$ and $\mathrm{H}_{2}-3\left[\delta_{\mathrm{H}} 3.93(\mathrm{dd}, J=9.7,5.5 \mathrm{~Hz})\right.$ and $\left.4.23(\mathrm{dd}, J=9.7,4.0 \mathrm{~Hz})\right]$ in 2 compared to the corresponding signals of $\mathrm{H}_{2}-1$ and $\mathrm{H}_{2}-3$ in 1. The downfield shift of $\mathrm{H}_{2}-3\left(\delta_{\mathrm{H}} 3.93\right.$ and 4.23) suggested that the glucose moiety in $\mathbf{2}$ was linked at $\mathrm{C}-3$ instead of $\mathrm{C}-1$ as in $\mathbf{1}$. This assumption was confirmed by HMBC correlation from anomeric proton $\mathrm{H}-1^{\prime}\left(\delta_{\mathrm{H}} 4.33\right)$ to $\mathrm{C}-3(\delta \mathrm{c} 70.5)$ (Figure 2 ). The relative and absolute configurations of $\mathbf{2}$ were determined to be the same as those of $\mathbf{1}$ by NOESY (Figure 3) and CD spectral data; thus, the structure of $\mathbf{2}$ was deduced to be 3-O- $\beta$-D-glucopyranoside of 6 .

\subsubsection{Chemical Structure of Lasianoside C}

Lasianoside $C(3),[\alpha]^{22} D^{-10.2}$, was obtained as viscous pale yellow syrup; it had a molecular formula of $\mathrm{C}_{25} \mathrm{H}_{30} \mathrm{O}_{13}$ with 11 degrees of unsaturation as determined by HR-ESI-MS (measured at $m / z$ : 
$561.1572[\mathrm{M}+\mathrm{Na}]^{+}$, calcd for $\mathrm{C}_{25} \mathrm{H}_{30} \mathrm{O}_{13} \mathrm{Na}$ : 561.1579). The UV spectrum showed absorption maxima at 329,300 , and $245 \mathrm{~nm}$, suggesting the presence of an aromatic ring. In the same way, the IR spectrum of 3 exhibited absorption bands at 3356, 1745, 1712, 1623, 1600, and $1512 \mathrm{~cm}^{-1}$, which suggested the presence of hydroxy, a five-membered lactone ring, conjugated ester carbonyl, $\alpha, \beta$-unsaturated olefinic carbons, and an aromatic ring, respectively. The ${ }^{13} \mathrm{C}-\mathrm{NMR}$ spectrum closely resembled that of 2 , except for the presence of an additional eight $\mathrm{sp}^{2}$ signals ( $\delta \mathrm{c} 114.8,115.2,116.5,123.1,127.6,146.8,147.3$, and 149.7) together with a carboxyl carbon signal ( $\delta c$ 169.1) (Table 2). Thus, compound 3 was expected to be an acylated derivative of 2 . Moreover, the ${ }^{1} \mathrm{H}-\mathrm{NMR}$ spectrum of $\mathbf{3}$ showed three ABX-coupled aromatic protons, $\mathrm{H}-2^{\prime \prime}$ at $\delta_{\mathrm{H}} 7.07(\mathrm{~d}, J=1.7 \mathrm{~Hz}), \mathrm{H}-5^{\prime \prime}$ at $\delta_{\mathrm{H}} 6.80(\mathrm{~d}, J=8.2 \mathrm{~Hz})$, and $\mathrm{H}-6^{\prime \prime}$ at $\delta_{\mathrm{H}} 6.98$ $(\mathrm{dd}, J=8.2,1.7 \mathrm{~Hz})$, and two trans-olefinic protons, $\mathrm{H}-7^{\prime \prime}$ at $\delta_{\mathrm{H}} 7.57(\mathrm{br} \mathrm{d}, J=15.9 \mathrm{~Hz})$ and $\mathrm{H}-8^{\prime \prime}{ }^{\prime}$ at $\delta_{\mathrm{H}}$ $6.30(\mathrm{br} \mathrm{d}, J=15.9 \mathrm{~Hz}$ ) (Table 1). This data implied that the acyl moiety is a trans-caffeoyl group. The esterification position was indicated to be at C- $6^{\prime}$ of the glucose moiety, due to the downfield shift of $\mathrm{H}_{2}-6^{\prime}$ to $\delta_{\mathrm{H}} 4.34(\mathrm{dd}, J=12.0,5.7 \mathrm{~Hz})$ and $4.57(\mathrm{dd}, J=12.0,1.8 \mathrm{~Hz})$. This assumption was confirmed by HMBC correlation from $\mathrm{H}_{2}-6^{\prime}\left(\delta_{\mathrm{H}} 4.34\right.$ and 4.57) to carbonyl carbon C-9" $(\delta \mathrm{c} 169.1)$, while the glucosylation position was indicated to be at $\mathrm{C}-3$ due to $\mathrm{HMBC}$ correlation from anomeric proton $\mathrm{H}-1^{\prime}\left(\delta_{\mathrm{H}} 4.37\right)$ to $\mathrm{C}-3(\delta \mathrm{c} 71.2)$ (Figure 2$)$. The acid hydrolysis of 3 released D-glucose, while alkaline hydrolysis afforded caffeic acid. These results were identified by HPLC comparing with authentic samples. The configuration of glucopyranose was assigned to be $\beta$ according to the coupling constant of the anomeric proton $\mathrm{H}-1^{\prime}$ at $\delta_{\mathrm{H}} 4.37(\mathrm{~d}, J=8.0 \mathrm{~Hz})$, while the caffeoyl configuration was determined as an E configuration according to the coupling constant of the olefinic protons $\mathrm{H}-\mathrm{7}^{\prime \prime}$ and $\mathrm{H}-\mathrm{8}^{\prime \prime}(\mathrm{J}=$ $15.9 \mathrm{~Hz}$ ). The relative and absolute configurations of 3 were determined by comparing its NOESY correlation (Figure 3) and CD spectrum to those of $\mathbf{2}$. Therefore, the structure of $\mathbf{3}$ was established to be 6'-caffeoyl-3-O- $\beta$-D-glucopyranoside of 6 , which was designated as lasianoside C.

\subsubsection{Chemical Structure of Lasianoside D}

Lasianoside $D(4),[\alpha]^{22} D^{-22.9}$, was also obtained as viscous pale yellow syrup with the molecular formula $\mathrm{C}_{27} \mathrm{H}_{32} \mathrm{O}_{14}$ with 12 degrees of unsaturation, which was deduced by the molecular ion peak $[\mathrm{M}+\mathrm{Na}]^{+}$at $\mathrm{m} / \mathrm{z}: 603.1685$ (calcd for $\mathrm{C}_{27} \mathrm{H}_{32} \mathrm{O}_{14} \mathrm{Na}$ : 603.1684) in HR-ESI-MS. Analysis of ${ }^{1} \mathrm{H}$ and ${ }^{13} \mathrm{C}$-NMR (Tables 1 and 2), together with the molecular formula revealed that compound 4 was an acetyl derivative of 3 . In the HMBC spectrum (Figure 2), downfield-shifted $\mathrm{H}_{2}-1\left(\delta_{\mathrm{H}} 4.75\right)$ showed correlation to the acetyl carbonyl carbon at $\delta c 172.6$, which indicated that 4 should be a 1-acetyl derivative of 3 . Further analyses of NMR data suggested that the other part of 4 was the same as that of 3 . The relative and absolute configurations of $\mathbf{4}$ were also identified to be the same as those of $\mathbf{3}$ by comparing the NOESY (Figure 3) and CD spectral data with those of 3; thus, the structure of 4 was elucidated to be 1-acetyl-6' -caffeoyl-3-O- $\beta$-D-glucopyranoside of 6 , and designated as lasianoside D.

\subsubsection{Chemical Structure of Lasianoside E}

Lasianoside $\mathrm{E}(5),[\alpha]^{22} \mathrm{D}^{-24.5}$, has the same molecular formula as that of 4 by HR-ESI-MS $(\mathrm{m} / \mathrm{z}$ : $603.1682[\mathrm{M}+\mathrm{Na}]^{+}$, calcd for $\mathrm{C}_{27} \mathrm{H}_{32} \mathrm{O}_{14} \mathrm{Na}$ : 603.1684). A further comparison of NMR data (Tables 1 and 2) displayed that compounds 5 and $\mathbf{4}$ shared the same functional group. In HMBC spectrum (Figure 2), a significant downfield shift of $\mathrm{H}_{2}-10\left(\delta_{\mathrm{H}} 4.67\right)$ showed correlation to acetyl carbonyl carbon at $\delta c$ 172.6. Detailed analyses of 2D NMR data indicated that the other part of 5 was the same as of that of 4 . The relative and absolute configurations of $\mathbf{5}$ were determined by comparison of the NOESY experiment (Figure 3) and CD data with those of 4 . Therefore, the structure of 5 was elucidated to be 10-acetyl-6'-caffeoyl-3-O- $\beta$-D-glucopyranoside of 6 , and designated as lasianoside E.

\subsection{Antioxidant and Cytotoxic Activities of Isolated Compounds}

Compounds 1-8 from the 1-BuOH fraction of L. verticillatus were evaluated for their DPPH radical scavenging activities. As shown in Table 3, lasianosides $\mathrm{C}$ and $\mathrm{D}$ ( 3 and 4$)$ displayed potent radical scavenging activities ( $\mathrm{IC}_{50}$ : $30.2 \pm 1.8$ and $32.0 \pm 1.2 \mu \mathrm{M}$, respectively) that were comparable with those 
of standard Trolox $\left(\mathrm{IC}_{50}: 29.2 \pm 0.39 \mu \mathrm{M}\right)$, while compound 5 exhibited moderate scavenging activity ( $\left.\mathrm{IC}_{50}: 46.4 \pm 2.3 \mu \mathrm{M}\right)$. Moreover, the remaining compounds did not possess significant DPPH radical scavenging properties $\left(\mathrm{IC}_{50}>100 \mu \mathrm{M}\right)$. These results suggested that the radical scavenging activities of 3-5 may be related to the presence of caffeoyl moieties in their structures $[19,20]$. On other hand, none of the isolated compounds exhibited cytotoxic activity against human lung cancer cell line (A549) as shown in Table 3, which coincided with our preliminary result for 1-BuOH extract $\left(\mathrm{IC}_{50}>100 \mu \mathrm{M}\right)$.

Table 2. ${ }^{13} \mathrm{C}-\mathrm{NMR}$ data of compounds $\mathbf{1}-\mathbf{5}\left(175 \mathrm{MHz}, \mathrm{CD}_{3} \mathrm{OD}, \delta\right.$ in ppm).

\begin{tabular}{cccccc}
\hline Position & $\mathbf{1}$ & $\mathbf{2}$ & $\mathbf{3}$ & $\mathbf{4}$ & $\mathbf{5}$ \\
\hline 1 & 64.4 & 56.8 & 58.4 & 59.4 & 57.1 \\
3 & 63.3 & 70.5 & 71.2 & 71.2 & 71.3 \\
4 & 48.4 & 46.8 & 46.9 & 47.0 & 46.8 \\
5 & 53.4 & 53.0 & 53.4 & 53.4 & 53.3 \\
6 & 83.2 & 83.3 & 83.4 & 83.3 & 83.2 \\
7 & 41.8 & 41.7 & 41.6 & 41.5 & 41.7 \\
8 & 140.2 & 138.5 & 138.5 & 142.0 & 133.4 \\
9 & 134.4 & 137.4 & 137.4 & 132.5 & 140.5 \\
10 & 58.4 & 58.4 & 57.0 & 58.5 & 60.9 \\
11 & 180.9 & 180.2 & 180.2 & 180.0 & 180.0 \\
12 & & & & 172.6 & 172.6 \\
13 & & & & 20.8 & 20.7 \\
$1^{\prime}$ & 103.8 & 104.6 & 104.8 & 104.8 & 104.9 \\
$2^{\prime}$ & 75.1 & 75.0 & 75.0 & 75.0 & 75.0 \\
$3^{\prime}$ & 78.0 & 77.9 & 77.7 & 77.8 & 77.7 \\
$4^{\prime}$ & 71.6 & 71.5 & 71.6 & 71.6 & 71.6 \\
$5^{\prime}$ & 78.0 & 78.1 & 75.5 & 75.5 & 75.5 \\
$6^{\prime}$ & 62.8 & 62.7 & 64.3 & 64.2 & 64.3 \\
$1^{\prime \prime}$ & & & 127.6 & 127.6 & 127.6 \\
$2^{\prime \prime}$ & & & 115.2 & 115.2 & 115.2 \\
$3^{\prime \prime}$ & & & 146.8 & 146.9 & 146.9 \\
$4^{\prime \prime}$ & & & 149.7 & 149.8 & 149.7 \\
$5^{\prime \prime}$ & & & 116.5 & 116.5 & 116.5 \\
$6^{\prime \prime}$ & & & 123.1 & 123.1 & 123.1 \\
$7^{\prime \prime}$ & & & 147.3 & 147.3 & 147.3 \\
$8^{\prime \prime}$ & & & 114.8 & 114.8 & 114.8 \\
$9^{\prime \prime}$ & & & & 169.0 & 169.1 \\
\hline
\end{tabular}

Table 3. Bioactivities of isolated compounds 1-8 $(\mathbf{n}=3)^{*}$. DPPH: 1,1-diphenyl-2-picrylhydrazyl.

\begin{tabular}{ccc}
\hline Isolated Compounds & DPPH $\left(\mathbf{I C}_{\mathbf{5 0}} \boldsymbol{\mu M}\right)$ & A549 Cytotoxicity $\left(\mathbf{I C}_{\mathbf{5 0}} \boldsymbol{\mu M}\right)$ \\
\hline Lasianoside A (1) & $>100$ & $>100$ \\
Lasianoside B (2) & $>100$ & $>100$ \\
Lasianoside C (3) & $30.2 \pm 1.8$ & $>100$ \\
Lasianoside D (4) & $32.0 \pm 1.2$ & $>100$ \\
Lasianoside E (5) & $46.4 \pm 2.3$ & $>100$ \\
Lasianol (6) & $>100$ & $>100$ \\
Deacetyl daphylloside (7) & $>100$ & $>100$ \\
Daphylloside (8) & $>100$ & - \\
Trolox & $29.2 \pm 0.39$ & $0.90 \pm 0.02$ \\
Doxorubicin & - &
\end{tabular}

* The results were obtained from three independent triplicate experiments, and the $\mathrm{IC}_{50}$ values were calculated by linear regression on Excel software. 


\section{Materials and Methods}

\subsection{General Method}

UV and IR spectra were obtained on a Jasco V-520 UV/Vis spectrophotometer and a Horiba FT-710 Fourier transform infrared spectrophotometer (Horiba, Kyoto, Japan), respectively. Optical rotations data were measured on a JASCO P-1030, while CD spectra were recorded on a Jasco J-720 circular dichroism spectrometer (Jasco, Tokyo, Japan). NMR experiments were measured on a Bruker AVANCE 500-MHz and 700-MHz spectrometers, with tetramethylsilane (TMS) as an internal standard (Bruker, Billerica, MA, USA). Positive ion HR-ESI-MS spectra were recorded using an LTQ Orbitrap XL mass spectrometer (Thermo Fisher Scientific, Waltham, MA, USA). Column chromatography (CC) was performed on a Diaion HP-20 (Mitsubishi chemical Corp., Japan), silica gel 60 (230-400 mesh, Merck, Germany), and octadecyl silica (ODS) gel (Cosmosil 75C 18 -OPN (Nacalai Tesque, Kyoto, Japan; $\Phi=35 \mathrm{~mm}, L=350 \mathrm{~mm})$, and TLC was performed on precoated silica gel plates $60 \mathrm{GF}_{254}(0.25 \mathrm{~mm}$ in thickness, Merck). HPLC was performed on ODS gel (Cosmosil $5 \mathrm{C}_{18}$-AR, Nacalai Tesque, Kyoto, $10 \mathrm{~mm}, 250 \mathrm{~mm}$, flow rate $2.5 \mathrm{~mL} / \mathrm{min}$ ) with a mixture of $\mathrm{H}_{2} \mathrm{O}$, acetone, and $\mathrm{MeOH}$, and the elute was monitored by refractive index and/or a UV detector. An amino column (Shodex Asahipak NH2P-50 $4 \mathrm{E}(4.6 \mathrm{~mm} \times 250 \mathrm{~mm}), \mathrm{CH}_{3} \mathrm{CN}-\mathrm{H}_{2} \mathrm{O}(3: 1) 1 \mathrm{~mL} / \mathrm{min}$ ) was used together with a chiral detector (Jasco OR-2090plus) for the HPLC analysis of sugars obtained after hydrolysis.

\subsection{Plant Material}

Leaves of Lasianthus verticillatus were collected from Iriomote Island, Okinawa Prefecture, Japan, in September 2000. The voucher specimen (IR0009-LT) was deposited at the department of pharmacognosy, faculty of pharmaceutical sciences, Hiroshima university.

\subsection{Extraction and Isolation}

The air-dried and powdered leaves of L. verticillatus (Lour.) Merr. (7.0 kg) were extracted by maceration with $\mathrm{MeOH}(98 \mathrm{~L} \times 2)$ and concentrated to $90 \% \mathrm{MeOH}$ solution; then, they were defatted with $3 \mathrm{~L}$ of $n$-hexane. The remaining solution was evaporated and re-suspended in $1 \mathrm{~L}$ of $\mathrm{H}_{2} \mathrm{O}$ and extracted with $3 \mathrm{~L}$ of EtOAc and $3 \mathrm{~L}$ of 1-BuOH, successively.

Part of the 1-BuOH fraction (124.5 g) was fractionated on a Diaion HP-20 column $(\Phi=10 \mathrm{~cm}$, $L=350 \mathrm{~cm}, 2.5 \mathrm{~kg})$, and eluted with $\mathrm{H}_{2} \mathrm{O}(15 \mathrm{~L})$, followed by an $\mathrm{MeOH} / \mathrm{H}_{2} \mathrm{O}$ step gradient solvent systems $(10 \%, 20 \%, 30 \%, 40 \%, 60 \%$, and 100\% MeOH, $15 \mathrm{~L}$ each, 1-L fractions being collected), similar fractions were grouped together to give 20 fractions (Fr. Lt1-Lt20). Fraction Lt8 (18.7 g) was proceeded on silica gel CC $(\Phi=4.5 \mathrm{~cm}, L=50 \mathrm{~cm}, 400 \mathrm{~g})$, started with $\mathrm{CHCl}_{3}(2.5 \mathrm{~L})$, and followed by $\mathrm{CHCl}_{3} / \mathrm{MeOH}$ developing solvent systems (7\%, 10\%, 15\%, 20\%, 30\%, and 100\% MeOH, $2.5 \mathrm{~L}$ each) to obtain 16 fractions (Fr. Lt8.1-Lt8.16). Each fraction of Lt8.12 (681 mg) and Lt8.13 (240 mg) was subjected to open reversed phase (ODS) CC with $10 \%$ aq. methanol $(400 \mathrm{~mL})$ to $100 \%$ methanol $(400 \mathrm{~mL})$, linear gradient, to give (Frs. Lt8.12.1-Lt8.12.6 and Frs. Lt8.13.1-Lt8.13.6, respectively). The residue Lt8.12.2 (131 mg) was purified by HPLC (ODS) with 5\% aq. methanol to give 1 (4.0 mg), while residue Lt8.13.2 (174 $\mathrm{mg}$ ) was purified by HPLC (ODS) with 5\% aq. methanol to give 6 (10.4 mg), 2 (5.0 mg). Fraction Lt13 $(4.3 \mathrm{~g})$ was proceeded on silica gel CC $(\Phi=4 \mathrm{~cm}, L=40 \mathrm{~cm}, 230 \mathrm{~g})$, started with $\mathrm{CHCl}_{3}(1.5 \mathrm{~L})$, and followed by $\mathrm{CHCl}_{3} / \mathrm{MeOH}$ developing solvent systems $(5 \%, 7 \%, 10 \%, 15 \%, 20 \%, 30 \%, 40 \%$, and $100 \%$ $\mathrm{MeOH}, 1.5 \mathrm{~L}$ each) to give 14 fractions (Frs. Lt13.1-Lt13.14). The residue Lt13.5 (455 mg) was purified by preparative HPLC (ODS) with $15 \%$ aq. acetone to give 7 (5.8 $\mathrm{mg})$ and $8(23.4 \mathrm{mg})$. The other residue Lt13.10 (215 mg) was purified by preparative HPLC (ODS) with 30\% aq. methanol to give 3 (6.0 mg). Fraction Lt15 (7.2 g) was chromatographed on silica gel CC $(\Phi=5.2 \mathrm{~cm}, L=38 \mathrm{~cm}, 350 \mathrm{~g})$, started with $\mathrm{CHCl}_{3}(2.5 \mathrm{~L})$, and followed by $\mathrm{CHCl}_{3} / \mathrm{MeOH}$ developing solvent systems (5\%, 10\%, 12\%, 15\%, 20\%, $30 \%$, and 100\% MeOH, $2.5 \mathrm{~L}$ each) to obtain 12 fractions (Frs. Lt15.1-Lt15.12). Fraction Lt15.5 (656 mg) was rechromatographed on silica gel CC $(\Phi=2.5 \mathrm{~cm}, L=50 \mathrm{~cm}, 120 \mathrm{~g})$, started with $\mathrm{CHCl}_{3}(500 \mathrm{~mL})$, and followed by $\mathrm{CHCl}_{3} / \mathrm{MeOH}$ developing solvent systems (5\%, 7\%, 10\%, 12\%, and 100\% $\mathrm{MeOH}$, 
$500 \mathrm{~mL}$ each) to give 11 fractions (Frs. Lt15.5.1-Lt15.5.11). Fraction Lt15.7 (577 mg) was separated by HPLC (ODS) with $28 \%$ aq. acetone to give $4(3.0 \mathrm{mg})$. The fraction LtB17 $(6.1 \mathrm{~g})$ was further purified by silica gel column chromatography $(\Phi=5 \mathrm{~cm}, L=40 \mathrm{~cm}, 380 \mathrm{~g})$, eluting with a stepwise $\mathrm{CHCl}_{3} / \mathrm{MeOH}$ gradient (100:0 to 70:30, 2.4 L each) to obtain 11 fractions (Frs. LtB17.1-LtB17.11). The residue LtB17.7 (839 $\mathrm{mg}$ ) was separated by HPLC, $28 \%$ aq. acetone to obtain 5 (7.0 mg).

\subsection{Spectroscopic Data of Compounds $\mathbf{1}-\mathbf{5}$}

Lasianoside A (1) Viscous colorless syrup $[\alpha]^{22} \mathrm{D}-20.6$ (c 0.30, MeOH); HR-ESI-MS: $m / z$ : 399.1263 $[\mathrm{M}+\mathrm{Na}]^{+}$(calcd for $\left.\mathrm{C}_{16} \mathrm{H}_{24} \mathrm{O}_{10} \mathrm{Na}, 399.1262\right) ; \mathrm{CD} \lambda_{\max }\left(c 2.66 \times 10^{-5} \mathrm{M}, \mathrm{MeOH}\right) \mathrm{nm}(\Delta \epsilon): 270(-0.059)$, 221 (+0.854); IR (film) $v_{\max }$ : 3390, 2921, 1748, 1194, 1072, $1032 \mathrm{~cm}^{-1} ;{ }^{1} \mathrm{H}$ and ${ }^{13} \mathrm{C}$ data, see Tables 1 and 2.

Lasianoside B (2) Viscous colorless syrup $[\alpha]^{22} \mathrm{D}-26.6$ (c 0.30, MeOH); HR-ESI-MS: $m / z: 399.1265$ [M+Na] ${ }^{+}$ (calcd for $\left.\mathrm{C}_{16} \mathrm{H}_{24} \mathrm{O}_{10} \mathrm{Na}, 399.1262\right) ; \mathrm{CD} \lambda_{\max }\left(c 2.66 \times 10^{-5} \mathrm{M}, \mathrm{MeOH}\right) \mathrm{nm}(\Delta \epsilon)$ : $281(-0.026), 217(+1.99)$; IR (film) $v_{\max }: 3372,2927,1754,1171,1078,1024 \mathrm{~cm}^{-1} ;{ }^{1} \mathrm{H}$ and ${ }^{13} \mathrm{C}$ data, see Tables 1 and 2.

Lasianoside C (3) Viscous pale yellow syrup $[\alpha]^{22}{ }_{\mathrm{D}}-10.2(c 0.34, \mathrm{MeOH})$; HR-ESI-MS: $m / z$ : 561.1572 $[\mathrm{M}+\mathrm{Na}]^{+}$(calcd for $\left.\mathrm{C}_{25} \mathrm{H}_{30} \mathrm{O}_{13} \mathrm{Na}, 561.1579\right) ; \mathrm{CD} \lambda_{\max }\left(c 1.85 \times 10^{-5} \mathrm{M}, \mathrm{MeOH}\right) \mathrm{nm}(\Delta \epsilon)$ : $283(-0.357)$, 221 (+6.155); UV (MeOH) $\lambda_{\max } \mathrm{nm}(\log \epsilon): 329$ (4.74), 300 (4.63), 245 (4.59); IR (film) $v_{\max }: 3356,2913$, $1745,1712,1623,1600,1512,1360,1274,1165,1032 \mathrm{~cm}^{-1} ;{ }^{1} \mathrm{H}$ and ${ }^{13} \mathrm{C}$ data, see Tables 1 and 2.

Lasianoside $D(4)$ Viscous pale yellow syrup $[\alpha]^{22}{ }_{D}-22.9(c 0.27$, MeOH); HR-ESI-MS: $m / z$ : 603.1685 $[\mathrm{M}+\mathrm{Na}]^{+}$(calcd for $\left.\mathrm{C}_{27} \mathrm{H}_{32} \mathrm{O}_{14} \mathrm{Na}, 603.1684\right) ; \mathrm{CD} \lambda_{\max }\left(c 1.40 \times 10^{-5} \mathrm{M}, \mathrm{MeOH}\right) \mathrm{nm}(\Delta \epsilon)$ : $276(-0.105)$, 208 (+1.010); UV (MeOH) $\lambda_{\max } \mathrm{nm}(\log \epsilon): 329$ (4.37), 295 (4.27), 233 (4.42); IR (film) $v_{\max }$ : 3396, 2920, 1746, 1732, 1713, 1634, 1608, 1518, 1355, 1264, 1163, $1032 \mathrm{~cm}^{-1} ;{ }^{1} \mathrm{H}$ and ${ }^{13} \mathrm{C}$ data, see Tables 1 and 2.

Lasianoside E (5) Viscous pale yellow syrup $[\alpha]^{22} \mathrm{D}-24.5$ (c 0.40, MeOH); HR-ESI-MS: $m / z$ : 603.1682 $[\mathrm{M}+\mathrm{Na}]^{+}$(calcd for $\left.\mathrm{C}_{16} \mathrm{H}_{24} \mathrm{O}_{10} \mathrm{Na}, 603.1684\right) ; \mathrm{CD} \lambda_{\max }\left(c 1.72 \times 10^{-5} \mathrm{M}, \mathrm{MeOH}\right) \mathrm{nm}(\Delta \epsilon): 281(-0.297)$, 214 (+1.324); UV (MeOH) $\lambda_{\max } \mathrm{nm}(\log \epsilon): 331$ (3.98), 292 (3.90), 240 (3.96); IR (film) $v_{\max }: 3361,2928$, 1747, 1738, 1714, 1625, 1602, 1509, 1365, 1271, 1179, $1030 \mathrm{~cm}^{-1} ;{ }^{1} \mathrm{H}$ and ${ }^{13} \mathrm{C}$ data, see Tables 1 and 2.

\subsection{Acid Hydrolysis}

The isolated compounds 1-5 (1.0 mg each) were hydrolyzed with $1 \mathrm{M} \mathrm{HCl}(1.0 \mathrm{~mL})$ at $80^{\circ} \mathrm{C}$ for $3 \mathrm{~h}$. The reaction mixtures were neutralized with amberlite IRA96SB $\left(\mathrm{OH}^{-}\right.$form $)$, and the resin was removed by filtration. Then, the filtrate was extracted with an equal volume of EtOAc. The aqueous layers were analyzed by HPLC with an amino column [Asahipak NH2P-50 4E, $\mathrm{CH}_{3} \mathrm{CN}-\mathrm{H}_{2} \mathrm{O}(3: 1), 1 \mathrm{~mL} / \mathrm{min}$ ] and a chiral detector (JASCO OR-2090plus) in comparison with D-glucose as authentic standard. The aqueous layers of hydrolyzed compounds showed a peak at $t_{\mathrm{R}} 8.15 \mathrm{~min}$, which coincided with that of D-glucose [21].

\subsection{Alkaline Hydrolysis}

Compounds 3, 4, and 5 (3.0 mg each) were prepared as solutions in 50\% aqueous 1,4-dioxane $(0.5 \mathrm{~mL})$. These solutions were treated with $10 \%$ aqueous $\mathrm{KOH}(0.5 \mathrm{~mL})$ and stirred at $37^{\circ} \mathrm{C}$ for $1 \mathrm{~h}$. The reaction mixtures were neutralized with an ion-exchange resin (Amberlite IR-120B ( $\mathrm{H}^{+}$-form), and then filtrated and evaporated. The residues were dissolved in EtOAc and subjected to HPLC analysis [Cosmosil $\mathrm{C}_{18}-\mathrm{PAQ}, \mathrm{MeOH}-\mathrm{H}_{2} \mathrm{O}$ (45:50), with $0.1 \%$ TFA, $\left.1 \mathrm{~mL} / \mathrm{min}\right)$ ] with UV (245 nm) detector to identify the caffeoyl moieties at $t_{\mathrm{R}} 11.42 \mathrm{~min}$ [22].

\subsection{DPPH Radical Scavenging Activity}

Free radical scavenging activity was evaluated by using a quantitative DPPH assay. The absorbance of various concentrations of test compounds dissolved in $100 \mu \mathrm{L}$ of $\mathrm{MeOH}$ in a 96-well microtiter plate was measured at $515 \mathrm{~nm}$ as $\left(\mathrm{A}_{\text {blank }}\right)$. Then, $100 \mu \mathrm{L}$ of DPPH solution $(200 \mu \mathrm{M})$ was added to each well. The plate was incubated in a dark chamber at room temperature for $30 \mathrm{~min}$ before measuring the 
absorbance $\left(\mathrm{A}_{\text {sample }}\right)$ again. The following equation was used to calculate the percentage inhibition of free radicals:

$$
\% \text { Inhibition }=\left[1-\left(\mathrm{A}_{\text {sample }}-\mathrm{A}_{\text {blank }}\right) /\left(\mathrm{A}_{\text {control }}-\mathrm{A}_{\text {blank }}\right)\right] \times 100
$$

where $\mathrm{A}_{\text {control }}$ is the absorbance of control (DMSO and all reagents, except for the test compound). Trolox was used as the positive control. Their $\mathrm{IC}_{50}$ values were determined based on three independent experiments [23].

\subsection{Cytotoxicity}

Human lung cancer cell proliferation assay was carried out by means of colorimetric MTT assay to evaluate both the potential for antitumor agents and the safety against human cells. The cell line (A549) was established through explant culture of lung carcinomatous tissue from a 58-year-old Caucasian male and frequently used for in vitro antitumor drug screening. In this study, we also aimed to elucidate the safety of our antioxidant compounds using this human cell line because of the ease of obtaining and culturing indefinitely rather than normal and primary cultures. The cells were cultured in Dulbecco's modified Eagle's medium (DMEM) supplemented with $10 \%$ heat-inactivated fetal bovine serum, amphotericin B $(5.6 \mu \mathrm{g} / \mathrm{mL})$, and kanamycin $(100 \mu \mathrm{g} / \mathrm{mL})$. In a 96-well plate, the various concentrations of test compounds were incubated with A549 cells $\left(5 \times 10^{3}\right.$ cells/well) in a $5 \%$ $\mathrm{CO}_{2}$ incubator at $37^{\circ} \mathrm{C}$ for $72 \mathrm{~h}$. Then, the cell shape, approximate number, and color of supernatants were checked by microscope to avoid an over or underestimation of the result obtained by the following colorimetric evaluation. Then, an MTT solution $(0.5 \mathrm{mg} / \mathrm{mL})$ was replaced in each well, and the plate was further incubated for $1.5 \mathrm{~h}$ to generate formazan crystals. Subsequently, the medium was completely removed; then, $100 \mu \mathrm{L}$ of DMSO was added to each well to dissolve the crystals. The optical density (OD) values were measured at $540 \mathrm{~nm}$ using a microplate reader. The percentage (\%) inhibition of cell growth was calculated using the following equation:

$$
\% \text { Inhibition }=\left[1-\left(\mathrm{A}_{\text {sample }}-\mathrm{A}_{\text {blank }}\right) /\left(\mathrm{A}_{\text {control }}-\mathrm{A}_{\text {blank }}\right)\right] \times 100
$$

where $\mathrm{A}_{\text {control }}$ is the absorbance of control (DMSO and all reagents, except for the test compound). Their $\mathrm{IC}_{50}$ values were determined based on three independent experiments [24].

\section{Conclusions}

In this study, the chemical composition of L. verticillatus leaves was studied for the first time and resulted in the isolation of five undescribed iridoid glucosides, lasianosides A-E (1-5), together with three known compounds (6-8). The chemical structures of the new compounds were elucidated on the basis of NMR and MS studies. The absolute configuration of the new compounds was determined by the CD method. The isolated five new compounds (1-5) have the same core structure lasianol (6), which is an iridane skeleton. It was first isolated from Lasianthus wallichii by our previous research [11]. Lasianol and its derivatives have never been isolated afterward until our present work. The uniqueness of the structure may be produced through the biosynthetic pathway depicted in Figure 4 . The branching point is the form of intermediate iridotrial, e.g., hemiacetal and keto forms for iridoid and the iridane skeleton, respectively. 
a)

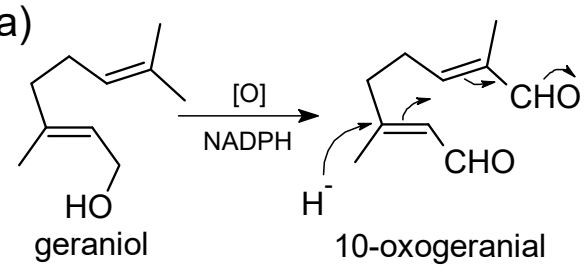<smiles>CC1CCC([C@H](C)C=O)C1CO</smiles><smiles>O=CC1=C(CO)[C@@H](O)[C@H](C(=O)O)C1C(=O)O</smiles>

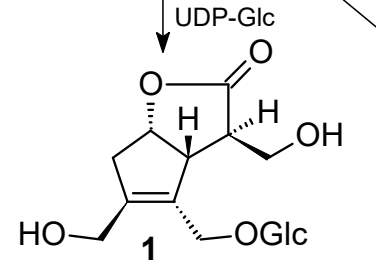<smiles>COC[C@H]1C(=O)O[C@H]2C[C@H](CO)C(CO)=C(CO)[C@@H]21</smiles>
(monocyclic form)<smiles>CC1CC[C@H]2C(C=O)=COC(O)[C@H]12</smiles>

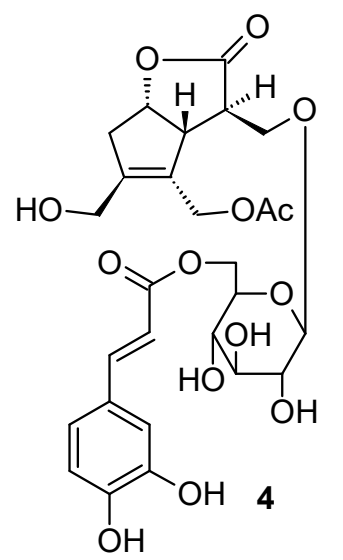

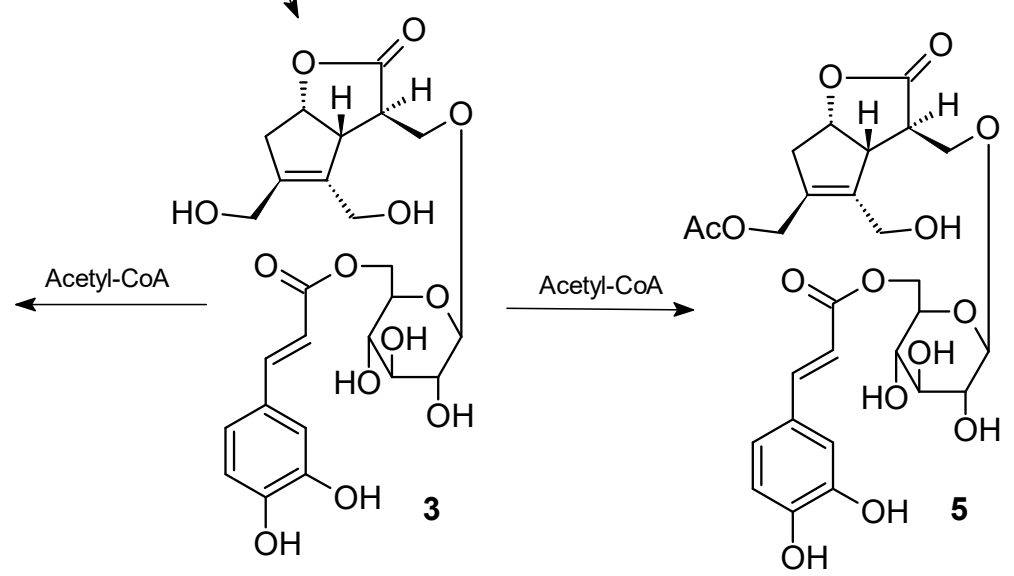

b)<smiles>[R]OC(=O)/C=C/c1ccc(O)c(O)c1</smiles><smiles>[R]OC(=O)/C=C/c1ccc(O)c(O)c1</smiles>

$3 a, 4 a, 5 a$<smiles>[R]OC(=O)/C=C/c1ccc(O)c(O)c1</smiles>

$3 b, 4 b, 5 b$<smiles>[R]OC(=O)/C=C/C1=CC(=O)C(=O)C=C1</smiles>

$3 c, 4 c, 5 c$

Figure 4. Plausible biosynthetic pathway of compounds 1-5, and possible antioxidant mechanism of compounds 3-5. (a) Plausible biosynthetic pathway. Iridotrial (keto form) is a common substrate for the production of iridane and iridoid skeletons. [O]; oxidation. (b) Possible antioxidant mechanism. The conjugated para-OH is the expected primary target of reactive oxygen species (ROS) to generate phenoxy radials $\mathbf{3}-\mathbf{5 a}$. The second ROS attack results in the formation of ortho quinones, $\mathbf{3}-\mathbf{5} \mathbf{c}$, through the resonance structures $3-5 b$. 
Plant species are potentially good sources for antioxidant secondary metabolites because of their habitats, being exposed continuously to sunlight, and thus gaining protection mechanisms against reactive oxygen species produced by UV irradiation [25]. The isolated compounds were tested for their antioxidant activities by DPPH free radical scavenging assay, and cytotoxicity against human lung cancer cell line (A549) by MTT assay. Among them, compounds 3 and 4 exhibited potent radical scavenging activity, while compound $\mathbf{5}$ showed moderate scavenging activity. The free radical scavenging activity of 3,4 , and 5 may be related to the presence of caffeoyl moieties in their structures. The possible reaction mechanism with reactive oxygen species is shown in Figure 4 according to the mechanism of catechol [26]. It is noteworthy that none of the isolated compounds exhibited cytotoxic activity against human lung cancer cell line A549 by the MTT method. Therefore, compounds 3,4 , and 5 have the potential to be safe antioxidant reagents to ameliorate a variety of oxidative stress-related diseases.

Supplementary Materials: The following are available online, Figures S1-S9: HR-ESI-MS, ${ }^{1} \mathrm{H},{ }^{13} \mathrm{C}$ NMR, DEPT, COSY, HSQC, HMBC, UV, and IR spectra of 1, Figures S10-S18: Spectra of 2, Figures S19-S28: Spectra of 3, Figures S29-S38: Spectra of 4, Figures S39-S48: Spectra of 5.

Author Contributions: K.M. (Katsuyoshi Matsunami) and G.A.A.-H. conceived and designed the experiment; G.A.A.-H. implement the experiments; G.A.A.-H. analyzed the data and wrote the original draft; K.M. (Kenta Mizuno), R.S.O., and S.P. analyzed the data; K.M. (Kenta Mizuno), S.S., and Y.Y. helped in experiments and contributed reagents/material and analysis tools; T.N. and K.M. (Kazuma Masuda) helped in the analysis of CD; Y.T. and H.O. performed the sample collection; K.M. (Katsuyoshi Matsunami) and R.S.O. supervised, K.M. (Katsuyoshi Matsunami) wrote, reviewed, and edited the manuscript.

Funding: This work was supported in part by the King Saud University External Joint Supervision Program (EJSP), Kingdom of Saudi Arabia, and by Grants-in-Aid from the Ministry of Education, Culture, Sports, Science and Technology of Japan, and the Japan Society for the Promotion of Science (Nos., 15H04651 and 17K15465, 17K08336 and 18K06740).

Acknowledgments: The measurements of HR-ESI-MS were performed with an LTQ Orbitrap XL spectrometer at the Natural Science Center for Basic Research and Development (N-BARD), Hiroshima University. The other experimental facilities and useful suggestions for publication of this work was kindly supported by a grant from the "Research Center of the Female Scientific and Medical Colleges", Deanship of Scientific Research, King Saud University.

Conflicts of Interest: The authors report no conflict of interest.

\section{References}

1. Pham-Huy, L.A.; He, H.; Pham-Huy, C. Free Radicals, Antioxidants in Disease and Health. Int. J. Biomed. Sci. 2008, 4, 89-96.

2. Lemjabbar-Alaoui, H.; Hassan, O.U.; Yang, Y.W.; Buchanan, P. Lung cancer: Biology and treatment options. Biochim. Biophys. Acta BBA Rev. Cancer 2015, 1856, 189-210. [CrossRef]

3. Newman, D.J.; Cragg, G.M. Natural Products as Sources of New Drugs from 1981 to 2014. J. Nat. Prod. 2016, 79, 629-661. [CrossRef]

4. Robbrecht, E. Tropical Woody Rubiaceae. In Opera Botanica Belgica; National Botanic Garden of Belgium: Meies, Belgium, 1988; Volume 1, p. 132.

5. Zhu, H. Two new subspecies of Lasianthus inodorus (Rubiaceae) from Kinabalu, Borneo, and their biogeographical implication. Bumea 2001, 46, 447-455.

6. Wiart, C. Medicinal Plants of the Asia-Pacific—Drugs for the Future; World Scientific Pub Co. Pte Lt.: Singapore, 2006; p. 588.

7. Napiroon, T.; Balslev, H.; Duangjai, S.; Sookchaloem, D.; Chayamarit, K.; Santimaleeworagun, W.; Vajrodaya, S. Antibacterial property testing of two species of tropical plant lasianthus (rubiaceae). Southeast Asian J. Trop. Med. Public Health 2017, 48, 117-123. [PubMed]

8. Li, B.; Zhang, D.M.; Luo, Y.M. A new sesquiterpene lactone from the roots of Lasianthus acuminatissimus. Acta Pharm. Sin. 2006, 41, 426-430.

9. Puff, C.; Chamchumroon, V. Non-indigenous Rubiaceae grown in Thailand. Thai. For. Bull. (Bot.) 2003, 31, 75-94. 
10. Yang, D.; Zhang, C.; Liu, X.X.; Wang, K.; Cheng, Z.Q. Chemical Constituents and Antioxidant Activity of Lasianthus hartii. Chem. Nat. Compd. 2017, 53, 390-393. [CrossRef]

11. Takeda, Y.; Shimidzu, H.; Mizuno, K.; Inouchi, S.; Masuda, T.; Hirata, E.; Shinzato, T.; Aramoto, M.; Otsuka, H. An Iridoid Glucoside Dimer and a Non-glucosidic Iridoid from the Leaves of Lasianthus wallichii. Chem. Pharm. Bull. 2002, 50, 1395-1397. [CrossRef]

12. Li, B.; Zhang, D.M.; Luo, Y.M.; Chen, X.G.; Zhang, D.; Luo, Y.; Chen, X. Three New and Antitumor Anthraquinone Glycosides from Lasianthus acuminatissimus Merr. Chem. Pharm. Bull. 2006, 37, 297-300. [CrossRef]

13. Li, B.; Lai, X.W.; Xu, X.H.; Yu, B.W.; Zhu, Y. A new anthraquinone from the root of Lasianthus acuminatissimus. Acta Pharm. Sin. 2007, 42, 502-504.

14. Li, B.; Zhang, D.M.; Luo, Y.M. Chemical constituents from root of Lasianthus acuminatissimus I. China J. Chin. Mater. Med. 2006, 31, 133-135.

15. Dallavalle, S.; Jayasinghe, L.; Kumarihamy, B.M.M.; Merlini, L.; Musso, L.; Scaglioni, L. A New 3, 4-seco-Lupane Derivative from Lasianthus gardneri. J. Nat. Prod. 2004, 67, 911-913. [CrossRef] [PubMed]

16. Zhu, H.; Roos, M.C.; Ridsdale, C.E. A taxonomic revision of the Malasian species of Lasianthus (Rubiaceae). Blumea 2012, 57, 1-102. [CrossRef]

17. Napiroon, T.; Tanruean, K.; Vajrodaya, S. Comparative phytochemical evaluation and biological control properties from Lasianthus verticillatus (Lour.) Merr. (Rubiaceae) extracts. Res. J. Biotechnol. 2019, 14, 41-49.

18. Demirezer, L.O.; Gurbuz, F.; Guvenlap, Z.; Stroch, K.; Zeeck, A. Iridoid, flavonoids and monoterpene glycosides from Galium verum subsp. Verum. Turk. J. Chem. 2006, 30, 525-534.

19. Masek, A. Determination of Antioxidant Activity of Caffeic Acid and p-Coumaric Acid by Using Electrochemical and Spectrophotometric Assays. Int. J. Electrochem. Sci. 2016, 11, 10644-10658. [CrossRef]

20. Moon, J.; Terano, J. Antioxidant activity of caffeic acid and dihydrocaffeic acid in lard and human low-density lipoprotine. J. Agric. Food Chem. 1998, 46, 5062-5065. [CrossRef]

21. Sugimoto, S.; Wanas, A.S.; Mizuta, T.; Matsunami, K.; Kamel, M.S.; Otsuka, H. Structure elucidation of secondary metabolites isolated from the leaves of Lxora undulate and their inhibitory activity toward advanced glycation end-products formation. Phytochemistry 2014, 108, 189-195. [CrossRef]

22. Yoshikawa, M.; Sugimoto, S.; Nakamura, S.; Matsuda, H. Medicinal flowers. XXII. Structures of chakasaponins $\mathrm{V}$ and VI, chakanoside I, and chakaflavonoside a from flower buds of Chinese tea plant (Camellia sinensis). Chem. Pharm. Bull. 2008, 56, 1297-1303. [CrossRef]

23. Matsunami, K.; Takamori, I.; Shinzato, T.; Aramoto, M.; Kondo, K.; Otsuka, K.; Takeda, Y. Radical-scavenging activities of new megastimane glucosides from Macaranga tanarius (L.) MULL-ARG. Chem. Pharm. Bull. 2006, 54, 1403-1407. [CrossRef] [PubMed]

24. Samy, M.N.; Sugimoto, S.; Matsunami, K.; Otsuka, H.; Kamel, M.S. One new flavonoid xyloside and one new natural triterpene rhamnoside from the leaves of Syzygium grande. Phytochem. Lett. 2014, 10, 86-90. [CrossRef]

25. Korkina, L.; Kostyuk, V.; Potapovich, A.; Mayer, W.; Talib, N.; De Luca, C. Secondary Plant Metabolites for Sun Protective Cosmetics: From Pre-Selection to Product Formulation. Cosmetics 2018, 5, 32. [CrossRef]

26. Valgimigli, L.; Amorati, R.; Fumo, M.G.; DiLabio, G.A.; Pedulli, G.F.; Ingold, K.U.; Pratt, D.A. The Unusual Reaction of Semiquinone Radicals with Molecular Oxygen. J. Org. Chem. 2008, 73, 1830-1841. [CrossRef] [PubMed]

Sample Availability: Samples of the compounds are available from the authors. 